\title{
Ecological Valuation of Mangrove Trees From Karimunjawa National Park as a Role in Carbon Sequestration to Maintain the Stability of Biodiversity
}

M Arief Rahman Halim ( $\nabla$ m.ariefrahmanha@gmail.com )

Universitas Diponegoro Sekolah Pascasarjana

Tri Retnaningsih Soeprobowati

Universitas Diponegoro Sekolah Pascasarjana

Hadiyanto Hadiyanto

Universitas Diponegoro Sekolah Pascasarjana

\section{Research Article}

Keywords: Mangrove, Karimunjawa National Park, Carbon Sequestration, sustainable management

Posted Date: January 25th, 2022

DOl: https://doi.org/10.21203/rs.3.rs-1241634/v1

License: (c) (i) This work is licensed under a Creative Commons Attribution 4.0 International License. Read Full License 


\section{Abstract}

The diversity of species in the mangrove ecosystem can be threatened if there is no database on what and how much content is in it. The research conducted in the mangrove ecosystem of Karimunjawa National Park has the objective of assessing species diversity and calculating the estimated carbon sequestration from stands and sediments. Inventory of species using quadrant sampling method consisting of 3 stations, 9 transects and 27 plots $(10 \mathrm{~m} \times 10 \mathrm{~m})$. Allometric equations, Shannon-Wiener index, and evenness index were used to calculate stand biomass and carbon, species diversity and distribution. The sediment samples were taken at a depth of $100 \mathrm{~cm}$ and divided into 3 depths, namely 0-33 cm, $34-67 \mathrm{~cm}$, and $68-100 \mathrm{~cm}$. The species diversity is moderate and the evenness of the species is in the stable category. The estimated standing carbon was in the range of $146.22 \mathrm{t} \mathrm{C} \mathrm{ha}^{-1}$ and the estimated carbon stock in the sediment was around $360.61 \mathrm{t} \mathrm{C} \mathrm{ha}^{-1}$. Although the diversity and even distribution of mangrove species in Karimunjawa National Park is still in a stable condition, it is necessary to monitor its changes due to the anthropogenic activities.

\section{Introduction}

Until now, mangroves are known as abrasion barriers against tsunamis and as important ecosystems that support the breeding of fish and crabs, but mangroves are also known to have an important function as a more effective absorber of carbon dioxide emissions when compared to rainforests or peatlands (Taillardat et al. 2018). Carbon dioxide emissions that make the earth warmer, encourage climate change and the loss of biodiversity, can come from motor vehicle fumes or various activities that use fossil fuels, such as electricity use, tourism and industrial activities (Wan et al. 2012). So, efforts to sequester carbon especially through rainforests and peatlands in Indonesia, are an important way to curb climate change and save living species from extinction (Roy et al. 2013).

Indonesia is indeed rich in forests and peatlands that are able to absorb carbon, but Indonesia is also one of the countries that has the largest mangrove forest in the world that is able to absorb more carbon than tropical forests or peatlands (Malik et al. 2015). It is noted that Indonesia has around three million hectares of mangrove forest or represents more than 20 percent of the world's mangroves, while Australia and Brazil in the second and third positions, only have about 900 thousand hectares (Huxham et al. 2015). Karimunjawa National Park is located in Jepara Regency, Central Java, is a representation of the integrity of the ecosystem of the northern coast of Java. As a conservation area that has very potential natural resources and high diversity. The mangrove ecosystem in Karimunjawa consists of Karimunjawa Island, Sintok, Mengawakan, Big Krakal, Small Krakal, Big Cemara, Small Cemara, Merican, Kemujan. The largest mangrove forests are on Karimunjawa Island and Kemujan Island with an area of 396.90 ha. Karimunjawa was designated a national park on February 29, 1988 by the Ministry of Forestry and is divided into nine zones, namely core zone, jungle zone, marine protection zone, land use zone, marine tourism utilization zone, marine cultivation zone, religious cultural and historical zone, rehabilitation zone, and traditional fishing zones. Karimunjawa is home to coral reefs, mangroves, coastal forests, and nearly 400 species of marine fauna, including 242 species of ornamental fish. Some of the rare fauna that live here are the White-breasted Sea Eagle, hawksbill turtles, and green turtles. Plants that characterize the Karimunjawa National Park are dewadaru (Crystocalyx macrophyla) which are found in lowland rain forests (BTNKJ 2020). Mangrove forests have a major role as carbon sinks and stores, which are around 4 gigatons $\mathrm{C} /$ year to 112 gigatons $\mathrm{C} /$ year (Cameron et al. 2019). Unfortunately, not all residents are aware of the importance of the function of the mangrove forest. On the other hand, mangrove forests are systematically degraded due to 
human interests (Basu and Cetzal 2018). There is a conversion of mangrove forest functions so that it has an impact on decreasing the ability to absorb carbon in the atmosphere and the decomposition of stored carbon through the decomposition process into the atmosphere (Ha et al. 2014). The role of the mangrove ecosystem as an absorber and a reservoir for $\mathrm{CO}_{2}$ turns into a contributor to $\mathrm{CO}_{2}$ emissions. These conditions contribute to climate change in the world (Datta et al. 2012). The potential for carbon storage in mangrove mud substrates is very large. Therefore, the estimation of carbon storage in the tree part and mangrove mud substrate can be used as a basic reference in assessing the ecological benefits of mangroves in the form of environmental service commodities (Carugati et al. 2018). Sustainable management of mangrove forests is suitable for stabilizing air quality because carbon will be absorbed and stored in the mangrove ecosystem (Li et al. 2010). Therefore, it is important to assess the level of diversity and evenness of mangrove species and to know the estimated carbon content stored in stands and sediments, which can later become a database so that in the future they can implement sustainable management of mangrove ecosystems.

\section{Materials And Methods \\ Study Area}

This research was conducted in the mangrove ecosystem of Karimunjawa National Park which is geographically located in $5^{\circ} 49^{\prime} 9^{\prime \prime S} 110^{\circ} 27^{\prime} 32^{\prime \prime E}$. Karimunjawa National Park is an archipelago in the Java Sea which is included in Jepara Regency, Central Java (Fig. 1). With a land area of $\pm 1,500$ hectares and waters of $\pm 110,000$ hectares. Sampling was in the mangrove area of Karimunjawa Island, Kemujan Island, and Menjangan Island. The sampling location was chosen based on the island which has a mangrove ecosystem and its condition is still natural.

\section{Data Collection}

Sampling was carried out non-destructively, which was carried out in August 2021. This study consisted of 3 stations, 9 transects and consisted of 27 plots $(10 \mathrm{~m} \times 10 \mathrm{~m})$ with a distance between plots of 10-20 m to facilitate inventory. The species of mangrove trees in the sample plot were identified and their diameter measured based on $\mathrm{DBH}$ (diameter of breast high) (Komiyama et al. 2008). The tree category includes a diameter of more than 10 $\mathrm{cm}$ and a tree height of more than 2 meters. Mangrove sediment samples were taken at 3 stations using a sediment core with a length of $100 \mathrm{~cm}$. The core sediments are divided into 3 depths, namely 0-33 cm, 34-67 cm, 68-100 cm. The level of sediment depth affects the amount of carbon content.

\section{Data Analysis}

To find out the important value index of an ecosystem, the sum of relative density, relative frequency, and relative dominance is done. Then to find the value of the diversity index $\left(\mathrm{H}^{\prime}\right)$ of a species, the Shanon Wiener equation is used:

$H^{\prime}=-\sum \mathrm{Pi} \ln (\mathrm{Pi})$

$\mathrm{H}^{\prime}=$ Shannon diversity, $\mathrm{s}=$ number of species, $\mathrm{pi}=$ proportion of the ith species. 
Species diversity is a characteristic of community level based on their biological organization. Species diversity can be used to express community structure. Species diversity can also be used to measure community stability, namely the ability of a community to maintain itself stable despite disturbances to its components.

The value of the species evenness index can describe the stability of a community. Evenness index value $(E)$ ranged from 0-1. The smaller the value of $E$ or close to zero, the more uneven the distribution of organisms in the community which is dominated by certain species and conversely the greater the value of $E$ or close to one, the organisms in the community will spread evenly. The equation for the evenness index is:

$\left.E=H^{\prime} / \log S\right)$

$\mathrm{E}=$ species evenness, $\mathrm{H}^{\prime}=$ Shannon diversity (the log of the number of species).

Calculation of biomass using the allometric formula by measuring the diameter at breast height (DBH). The allometric equation used is based on the reference from the Forestry Research and Development Agency No.P.01/VIII-P3KR/2012 by using the approach to the availability of a tree biomass allometric model that is appropriate to the type/forest ecosystem where the object is located but not at the location of the object. After the biomass is known, it is then multiplied by 0.47 to determine the carbon content, then converted into a unit area $\left(\right.$ ton $\left.\mathrm{ha}^{-1}\right)$. The carbon content of mangrove sediments was analyzed in the laboratory using the Walkley \& Black method (ton ha-1), then the sediment layer samples were analyzed for the purpose of obtaining sediment grain size data. The results of the sediment size analysis carried out in this laboratory are used to determine each size class based on the Wenworth scale. In addition, the grain size of the resulting sediment is also used to determine the type of sediment in the study area based on the Sheppard triangle.

\section{Results And Discussion}

\section{Species Mangrove in Karimunjawa National Park}

The composition of species, the number of trees, the average diameter at breast height and the average tree height of the mangrove ecosystem of Karimunjawa National Park are shown in Table 1. This study was divided into three stations focused on three islands, namely Karimunjawa Island, Kemujan Island, and Menjangan Island. Each island or observation station consists of three transects. It can be seen in Table 1 that at each research station there are mangrove species Rhizophora apiculate, Rhizophora mucronate, Ceriops tagal, Rhizophora stylosa and Xylocarpus moluccensis. The distribution is even because these species are natural mangrove species in the Karimunjawa National Park. The order of the total number of trees from the most to the least is station one (228 trees), station three (222 trees), station two (188 trees). The species that dominated the highest number of trees in all research locations was Rhizophora apiculata. According to Wetlands International, this species grows in silty, smooth, deep soil and is flooded during normal tides (Andradi et al. 2013). Prefers tidal waters that have a strong permanent influence of fresh water input. Rhizophora apiculate has a dominance level that reaches $90 \%$ of the vegetation that grows in a location. This is in accordance with the substrate conditions in the mangrove ecosystem of Karimunjawa National Park where many Rhizophora apiculate species grow and develop because their habitat is very suitable. The type and magnitude of the substrate percentage at each station can be seen in Fig. 2. 
Table 1

Composition of Mangrove Species in Karimunjawa National Park

\begin{tabular}{|c|c|c|c|c|}
\hline Station & Species & No. of trees & Mean DBH & Mean Height \\
\hline \multirow[t]{6}{*}{1} & Rhizophora apiculata & 99 & 22,26 & 9,40 \\
\hline & Rhizophora mucronata & 38 & 22,46 & 7,70 \\
\hline & Ceriops tagal & 41 & 22,84 & 6,10 \\
\hline & Rhizophora stylosa & 36 & 13,83 & 6,80 \\
\hline & Sonneratia caseolaris & 9 & 13,36 & 6,50 \\
\hline & Xylocarpus moluccensis & 5 & 14,9 & 7,10 \\
\hline \multirow[t]{6}{*}{2} & Rhizophora apiculata & 59 & 15 & 8,20 \\
\hline & Rhizophora mucronata & 49 & 14,64 & 6,00 \\
\hline & Ceriops tagal & 34 & 10,23 & 6,40 \\
\hline & Rhizophora stylosa & 23 & 14 & 6,60 \\
\hline & Xylocarpus moluccensis & 12 & 11,87 & 6,80 \\
\hline & Sonneratia caseolaris & 11 & 15,53 & 5,50 \\
\hline \multirow[t]{5}{*}{3} & Rhizophora apiculata & 65 & 15,25 & 7,70 \\
\hline & Rhizophora mucronata & 52 & 15,1 & 7,20 \\
\hline & Ceriops tagal & 52 & 10,79 & 7,25 \\
\hline & Rhizophora stylosa & 33 & 15,35 & 7,00 \\
\hline & Xylocarpus moluccensis & 20 & 11,22 & 6,60 \\
\hline
\end{tabular}

\section{Sediment Characteristics}

Based on Fig. 2 above, the type of sediment found in the three research sites is dominated by silt sediment, an average of $58 \%$. Sediment conditions at a depth of $0-100 \mathrm{~cm}$ tend to be textured like sandy mud with a little clay. According to Komiyama et al (2005) the type of mangrove Rhizophora sp can grow well with a sandy loam texture. Because of the strong roots of Rhizpora and effective in sand traps. The condition of mangroves has a sandy loam substrate, this is because the location of the mangrove ecosystem is not too close to the beach which has high currents or waves. According to Indah et al (2008), which stated that the root forms of Rhizophora sp. anchoring and tight also causes the formation of a substrate. The formation of this substrate is strongly influenced by the presence of currents in tidal and ebb conditions which carry the particles deposited at low tide. Oceanographic factors that affect the distribution of sediments are currents and depth (Wickramasinghe et al. 2009). Waters that have relatively calm currents and shallow water depths between $16-20 \mathrm{~cm}$ so that the types of sediments distributed in the mangrove ecosystem are similar. This is due to the anchored and tight root forms of Rhizophora sp which also causes the formation of a substrate (Ortega et al. 2018). These roots make the process of capturing dust particles in Rhizophora sp stands run perfectly (Morton 2016). When there is a backflow, the 
dust particles are blocked by the roots. This shows the characteristics of the sediments that are suitable for the growth of mangroves in the Karimunjawa National Park which are dominated by Rhizophora sp.

\section{Mangrove Species Diversity}

Important Value Index (INP) is an index that is calculated based on the amount obtained to determine the level of species dominance in a plant community (Pollisco and Simorangkir 2013). To determine the Important Value Index in mangrove vegetation trees can be obtained from the sum of the relative frequency, relative density, and relative dominance of a vegetation expressed in percent (\%). From the results of calculations that have been carried out at the three observation stations, it can be seen that there are differences in the value of the Important Value Index for each type of mangrove, where Rhizophora apiculata found at station I has the highest Important Value Index, which is $113.25 \%$ while the lowest important value index is owned by vegetation. Xylocarpus moluccensis mangrove species found in station I amounted to $15.82 \%$. The Important Value Index shows the range of the index that describes the community structure and distribution pattern of mangroves (Owuor et al. 2019). The difference in the index of the importance of mangrove vegetation is due to competition in each species to get nutrients and sunlight at the research site. Apart from nutrients and the sun, other factors that cause differences in the density of mangrove vegetation are the type of sediment and tides (Sarker et al. 2019).

The results of the analysis of the relative density of mangroves in Karimunjawa National Park presented in Table 2 shows that at the tree level the highest relative density is Rhizophora apiculata, which is $43.42 \%$ at station I, while the lowest relative density is Xylocarpus moluccensis, which is 2, 91\% of which are at station I as well. The high relative density of Rhizophora apiculata is because this mangrove has a high ability to adapt so that it can develop well. The low density of Xylocarpus moluccensis is due to the fact that this species is not covered by the study area and is more commonly found near land.

Species frequency is one of the vegetation parameters that can show the distribution pattern or distribution of plant species in the ecosystem or show the distribution pattern of plants. The frequency value is influenced by the value of the plot where mangrove species are found. The more the number of squares found, the higher the frequency of the presence of mangrove species (Sidik et al. 2018). The results of the analysis of the relative frequency of mangroves that have been carried out in the mangrove ecosystem of Karimunjawa National Park at the highest tree level are at station III, which is the same as $20 \%$. The species are Rhizophora apiculate, Rhizophora mucronate, Ceriops tagal, Rhizophora stylosa, and Xylocarpus moluccensis. Meanwhile, the lowest relative frequency at the tree level is Sonneratia caseolaris, which is $11.76 \%$ at station II. The large number of Rhizophora apiculate species is due to the condition of the sediment substrate at the study site in the form of sandy silt which is able to support mangrove growth so that this type of mangrove can survive and develop well. The silt substrate that is spread in almost all stations contains a lot of organic matter when compared to the type of sediment in the form of sand because it only contains minerals (Sarathchandra et al. 2018). Furthermore, the typical life cycle of Rhizophora with seeds that can germinate when they are still on the parent plant is very supportive of the wide distribution process of this species in the mangrove ecosystem (Thatoi et al. 2012).

At the tree level, the highest relative dominance value was occupied by Rhizophora apiculate with a dominance value of $51.08 \%$ at station I. This was because Rhizophora apiculate was able to compete to obtain more nutrients than other species due to the adaptation of its root system. Meanwhile, the dominance value which is relatively low is Xylocarpus moluccensis, which is $1.13 \%$. This is due to the uneven distribution of Xylocarpus 
moluccensis and the level of habitat suitability, where the substrate type in the Karimunjawa mangrove ecosystem is mostly silt-sand type, while Xylocarpus moluccensis prefers a harder substrate. 
Table 2

Value of Relative Frequency, Relative Dominance, Relative Density, Important Value Index, Diversity Index, and Evenness Index

\begin{tabular}{|c|c|c|c|c|c|c|c|c|c|}
\hline \multirow[t]{2}{*}{ St } & \multirow[t]{2}{*}{ Species } & \multirow{2}{*}{$\begin{array}{l}\text { Total } \\
\text { Individual }\end{array}$} & \multicolumn{3}{|c|}{ Relative values (\%) } & \multirow{2}{*}{$\begin{array}{l}\text { Importance } \\
\text { value (\%) }\end{array}$} & \multirow[t]{2}{*}{$\mathrm{H}^{\prime}$} & \multirow[t]{2}{*}{$E$} & \multirow[t]{2}{*}{ IUCN } \\
\hline & & & Frequency & Dominance & Density & & & & \\
\hline \multirow[t]{7}{*}{1} & $\begin{array}{l}\text { Rhizophora } \\
\text { apiculata }\end{array}$ & 99 & 18,75 & 51,08 & 43,42 & 113,25 & 0,36 & \multirow[t]{7}{*}{0,82} & LC \\
\hline & $\begin{array}{l}\text { Rhizophora } \\
\text { mucronata }\end{array}$ & 38 & 18,75 & 20,27 & 16,66 & 55,69 & 0,29 & & LC \\
\hline & $\begin{array}{l}\text { Ceriops } \\
\text { tagal }\end{array}$ & 41 & 18,75 & 7,48 & 17,98 & 44,21 & 0,30 & & LC \\
\hline & $\begin{array}{l}\text { Rhizophora } \\
\text { stylosa }\end{array}$ & 36 & 18,75 & 18,26 & 15,78 & 52,80 & 0,29 & & LC \\
\hline & $\begin{array}{l}\text { Sonneratia } \\
\text { caseolaris }\end{array}$ & 9 & 12,5 & 1,76 & 3,94 & 18,20 & 0,12 & & LC \\
\hline & $\begin{array}{l}\text { Xylocarpus } \\
\text { moluccensis }\end{array}$ & 5 & 12,5 & 1,13 & 2,19 & 15,82 & 0,08 & & LC \\
\hline & Total & 228 & 100 & 100 & 100 & 300 & 1,47 & & \\
\hline \multirow[t]{7}{*}{2} & $\begin{array}{l}\text { Rhizophora } \\
\text { apiculata }\end{array}$ & 59 & 17,64 & 20,02 & 31,38 & 69,05 & 0,36 & \multirow[t]{7}{*}{0.90} & LC \\
\hline & $\begin{array}{l}\text { Rhizophora } \\
\text { mucronata }\end{array}$ & 49 & 17,64 & 17,72 & 26,06 & 61,43 & 0,35 & & LC \\
\hline & $\begin{array}{l}\text { Ceriops } \\
\text { tagal }\end{array}$ & 34 & 17,64 & 13,32 & 18,08 & 49,05 & 0,31 & & LC \\
\hline & $\begin{array}{l}\text { Rhizophora } \\
\text { stylosa }\end{array}$ & 23 & 17,64 & 17,25 & 12,23 & 47,13 & 0,26 & & LC \\
\hline & $\begin{array}{l}\text { Xylocarpus } \\
\text { moluccensis }\end{array}$ & 12 & 17,64 & 13,97 & 6,38 & 38,00 & 0,18 & & LC \\
\hline & $\begin{array}{l}\text { Sonneratia } \\
\text { caseolaris }\end{array}$ & 11 & 11,76 & 17,72 & 5,85 & 35,33 & 0,17 & & LC \\
\hline & Total & 188 & 100 & 100 & 100 & 300 & 1,62 & & \\
\hline \multirow[t]{5}{*}{3} & $\begin{array}{l}\text { Rhizophora } \\
\text { apiculata }\end{array}$ & 65 & 20 & 24,73 & 29,28 & 74,01 & 0,36 & \multirow[t]{5}{*}{0,95} & LC \\
\hline & $\begin{array}{l}\text { Rhizophora } \\
\text { mucronata }\end{array}$ & 52 & 20 & 24,25 & 23,42 & 67,67 & 0,34 & & LC \\
\hline & $\begin{array}{l}\text { Ceriops } \\
\text { tagal }\end{array}$ & 52 & 20 & 13,82 & 23,42 & 57,25 & 0,34 & & LC \\
\hline & $\begin{array}{l}\text { Rhizophora } \\
\text { stylosa }\end{array}$ & 33 & 20 & 23,61 & 14,86 & 58,48 & 0,28 & & LC \\
\hline & $\begin{array}{l}\text { Xylocarpus } \\
\text { moluccensis }\end{array}$ & 20 & 20 & 13,58 & 9,01 & 42,59 & 0,22 & & LC \\
\hline
\end{tabular}




\begin{tabular}{|c|c|c|c|c|c|c|c|c|c|}
\hline \multirow[t]{2}{*}{ St } & \multirow[t]{2}{*}{ Species } & \multirow{2}{*}{$\begin{array}{l}\text { Total } \\
\text { Individual }\end{array}$} & \multicolumn{3}{|c|}{ Relative values (\%) } & \multirow{2}{*}{$\begin{array}{l}\text { Importance } \\
\text { value (\%) }\end{array}$} & \multirow[t]{2}{*}{$H^{\prime}$} & \multirow[t]{2}{*}{$E$} & \multirow[t]{2}{*}{ IUCN } \\
\hline & & & Frequency & Dominance & Density & & & & \\
\hline & Total & 222 & 100 & 100 & 100 & 300 & 1,54 & & \\
\hline
\end{tabular}

The diversity of mangrove species in the study area based on the Shannon-Wienner diversity index $\left(H^{\prime}\right)$ was in the moderate category at all stations. The data in Table 2 shows that for tree growth rates, the diversity index $\left(\mathrm{H}^{\prime}\right)$ ranges from $\mathrm{H}^{\prime} 1.47$ to 1.62 . This shows that the mangrove ecosystem has moderate diversity, the condition of the ecosystem is quite balanced, the water conditions are still stable, and the ecological pressure is moderate. The value of diversity in a community depends on the number of species and the number of individuals in the community. The species diversity of a community will be high if the community is composed of many species and no species dominates (Rahmila and Halim 2018). Conversely, a community has a low value of species diversity, if the community is composed of a few species and there is a dominant species. The mangrove vegetation found showed varying zoning at each station. These mangroves do not fully form zoning based on their tolerance to salinity and periods of inundation as suggested by many mangrove experts. In this study, mangroves grow from the edge of the sea to the mainland. The part near the sea is dominated by Rhizophora apiculata. This species is very dominant along the coastline of Karimunjawa Island, Kemujan Island, Menjangan Island. Sonneratia caseolaris, Ceriops tagal, Rhizophora stylosa and Rhizophora mucronata are at the rear, while Xylocarpus moluccensis and other minor component mangrove species fill the rear zone. This mangrove vegetation profile diagram shows that there are differences in mangrove zoning at each research station, especially for the rear zoning, while the front zoning tends to be uniform, dominated by Rhizophora apiculate. According to the conservation status of the IUCN red list, all mangrove species found in the study in Karimunjawa National Park are included in the least concern (LC) category. Although it is still classified as low risk, it is not impossible that in the next few years the number of species will be threatened along with the increase in anthropogenic activities in Karimunjawa National Park. So that conservation efforts need to be carried out

Furthermore, the evenness index value at each research station ranged from $0.82-0.95$. Based on the evenness index criteria, this value is stable for all stations. This shows that the species found at each research station tend to have uniformity, meaning that no particular species dominates a station. If the value of the evenness index is small, then the species uniformity in the community is lacking, meaning that the number of individuals for each species is not the same, so there is a tendency to be dominated by certain species (Zhila et al. 2013). On the other hand, the higher the uniformity index value, the higher the distribution pattern in the community and no particular species is dominant.

Distribution patterns in clusters are generally found in nature, due to the need for the same environmental factors (Syahid et al. 2020). There are a number of reasons why plants show a clumped distribution (Mangora 2011). Most of the mangrove seeds/fruits are not consumed by animals, so the ripe fruit will fall near the parent tree and will grow into an adult tree. According to Santos et al (2014), that the formation of a clustered distribution pattern is related to the pattern or way of eating because in certain areas there are many food sources. In addition, external reproduction factors and the characteristics of the substrate that are suitable for mangrove growth are one of the factors for the formation of a group distribution pattern. 
Table 3 shows the stand biomass yield, stand carbon content, and sediment carbon content. The value of biomass and carbon in the stand is directly proportional because the larger the diameter of the stand and the greater the density, the greater the biomass and carbon content. It can be seen that station 1 has the highest carbon content among the other stations. This is because at station 1 the mangrove ecosystem is included in the national park area, so that the condition of the stands and the condition of the surrounding environment are still very natural. This case is different from what happened at station 2 . The condition of mangroves located on the southern coast of Kemujan Island has been damaged a lot. This is presumably because there are residential residents around the mangrove area which causes the conversion of mangrove land to agricultural land. There is agricultural land for tropical crops such as rice and coconut plantations which can be seen in Fig. 1. Organic carbon in sediment is one of the constituents of organic compounds in the waters. Organic carbon is a priority for soil improvement and for carbon storage. The ability to store carbon is higher than the mangrove tree itself. There is a high potential for emissions due to disruption of large carbon stores. Table 4 shows the carbon content based on depth and total carbon content in the Karimunjawa mangrove ecosystem.

At stations $1-3$, the carbon content increases with increasing depth. The high organic matter in the surface layer $(0 \mathrm{~cm})$ is due to the high litter production from each station, where the mangrove density also affects the level of organic matter content. This is in accordance with Oliver et al (2012) opinion, which states that the decomposition process of litter (leaves/branches/twigs) only occurs on the surface of the soil, whereas at a depth of more than $20 \mathrm{~cm}$ the effect of this process is not significant (Moriizumi et al. 2010). The condition of the sustainability of subsurface carbon stocks in particular is still poorly understood, but evidence from this study shows that land clearing, drainage, and/or conversion to ponds/agriculture, in addition to having an impact on vegetation biomass, also significantly reduces the carbon content of mangrove soils.

Table 3

Value of Above-ground Biomass, C-stock, and Average C-stock at All Station

\begin{tabular}{|c|c|c|c|c|}
\hline & Transek & Above-ground Biomass ( $\mathrm{tha}^{-1}$ ) & C-Stock $\left(\mathrm{t} \mathrm{C} \mathrm{ha}^{-1}\right)$ & Average C-Stock $\left(\mathrm{t} \mathrm{C} \mathrm{ha}{ }^{-1}\right)$ \\
\hline \multirow[t]{3}{*}{ St 1} & 1 & 638,79 & 300,23 & \multirow[t]{3}{*}{243,73} \\
\hline & 2 & 427,8 & 201,07 & \\
\hline & 3 & 489,13 & 229,89 & \\
\hline \multirow[t]{3}{*}{ St 2} & 4 & 240,29 & 112,93 & \multirow[t]{3}{*}{94,01} \\
\hline & 5 & 177,75 & 83,54 & \\
\hline & 6 & 182,04 & 85,56 & \\
\hline \multirow[t]{3}{*}{ St 3} & 7 & 244,27 & 114,80 & \multirow[t]{3}{*}{100,92} \\
\hline & 8 & 193,37 & 90,88 & \\
\hline & 9 & 206,58 & 97,09 & \\
\hline
\end{tabular}


Table 4

Value of Carbon Content by Depth

\begin{tabular}{|c|c|c|c|}
\hline Station & Depth & Total Soil C-Stock & Total Soil C-Stock $\left(\mathrm{t} \mathrm{C} \mathrm{ha}^{-1}\right)$ \\
\hline \multirow[t]{3}{*}{1} & Depth $0-33 \mathrm{~cm}$ & 156,00 & \multirow[t]{3}{*}{482} \\
\hline & Depth $34-67 \mathrm{~cm}$ & 165,00 & \\
\hline & Depth $68-100 \mathrm{~cm}$ & 161,00 & \\
\hline \multirow[t]{3}{*}{2} & Depth $0-33 \mathrm{~cm}$ & 64,00 & \multirow[t]{3}{*}{199,75} \\
\hline & Depth $34-67 \mathrm{~cm}$ & 67,50 & \\
\hline & Depth $68-100 \mathrm{~cm}$ & 68,25 & \\
\hline \multirow[t]{3}{*}{3} & Depth $0-33 \mathrm{~cm}$ & 127,00 & \multirow[t]{3}{*}{400,1} \\
\hline & Depth $34-67 \mathrm{~cm}$ & 137,10 & \\
\hline & Depth $68-100 \mathrm{~cm}$ & 136,00 & \\
\hline
\end{tabular}

The results of measurements of carbon content at the three stations based on depth have different results of carbon storage (Fig. 3). The carbon storage value was measured vertically with five different depths while the measured depths were 0-33 cm, 34-67 cm, 68-100 cm. Where each depth has a different carbon storage value. The highest carbon storage on average is at a depth of $34-67 \mathrm{~cm}$ with values ranging from 67.5 to $165 \mathrm{t} \mathrm{C} \mathrm{ha}^{-1}$. The lowest value was found in the upper layer $(0-33 \mathrm{~cm})$ at station 2 with a value of $64 \mathrm{t} \mathrm{C} \mathrm{ha-1}$. This condition is thought to be because the surface layer is heavily affected by currents, waves, and tides which cause organic content including carbon to be carried along with the movement of water (Halim et al. 2018). While the layer below it has been in the form of solids that have fused over the years through the sedimentation process. From the sedimentation process, there is a biogeochemical process that causes the carbon content at the bottom to increase with increasing depth. The biogeochemical cycle is the transfer of elements/compounds involving organic and inorganic (Alongi 2020). The function of the biogeochemical cycle is to maintain life on earth. The total average value for the estimated carbon of mangrove stands is $146.22 \mathrm{t} \mathrm{C} \mathrm{ha}^{-1}$ and for the estimated carbon stock in sediments it is around $360.61 \mathrm{t} \mathrm{C} \mathrm{ha}^{-1}$. The estimated carbon of mangrove stands in Karimunjawa National Park is lower than the carbon content in the coastal village of Botoc Philippines (Abino et al. 2013). However, the estimated carbon content of sediments in Karimunjawa National Park is almost twice as high as $360.61 \mathrm{t} \mathrm{C} \mathrm{ha}{ }^{-1}$. On a national scale, the carbon content in the mangrove sediments of Karimunjawa National Park is higher than that of mangrove forests in Mangunharjo (Hadiyanto et al. 2021), Baturapa (Marbun et al. 2020), the northern part of the mangrove ecosystem of Bunaken National Park (Verisandria et al. 2018), Jembrana Bali (Mahasani et al., 2015). According to Komiyama et al. (2008) in a study of mangrove forest biomass in various countries that was carried out for several years, variations in biomass estimates did not only depend on species but also on ecological conditions and geographical locations. With a relatively high density value in the Karimunjawa mangrove ecosystem, the potential for litter fall is also expected to be very high. Different values of carbon content are influenced by the number and density of trees, tree species, environmental factors including sunlight, water content, temperature, and soil fertility that affect the rate of photosynthesis (Alongi 2002). The mangrove ecosystem is one of the most important ecosystems in the effort to maintain the 
stability of flora-fauna diversity and mitigate global warming, namely as the best carbon storage compared to all other forest types on earth.

\section{Conclusion}

Karimunjawa National Park has a stable mangrove ecosystem and sufficient species diversity. With conditions that are still natural, special attention is needed in sustainable management. The potential for carbon sequestration on a national scale is quite high both in stands (146.22 $\left.\mathrm{t} \mathrm{C} \mathrm{ha}^{-1}\right)$ and in sediments $(360.61 \mathrm{t} \mathrm{C}$ $\left.\mathrm{ha}^{-1}\right)$. The main factors that influence this are the density of species and the diameter of mangrove trunks. However, there is a threat from anthropogenic activities and the impact of climate change that can make the mangrove ecosystem vulnerable.

\section{Declarations}

\section{Acknowledgements}

The authors would like to thank the Karimunjawa National Park Office and the coastal communities of Karimunjawa District for their assistance during data collection. This research was carried out with the support of Research Grant for Disertation (Penelitian Disertasi Doktor) from the Ministry of Research and Technology of the Republic of Indonesia/BRIN [Project Number 187-49/UN7.6.1/PP/2021].

\section{Funding}

The first, second, and third authors have received research support from the Ministry of Research and Technology of the Republic of Indonesia/BRIN [Project Number 187-49/UN7.6.1/PP/2021].

\section{Competing Interests}

The authors have no relevant financial or non-financial interests to disclose.

\section{Author Contributions}

All authors contributed to the conception and design of the study. Material preparation, data collection and analysis were carried out by M. Arief Rahman Halim, Tri Retnaningsih Soeprobowati, and Hadiyanto. The initial draft of the manuscript was written by M. Arief Rahman Halim and all authors commented on the previous version of the manuscript. All authors read and approved the final manuscript.

\section{Data Availability}

The datasets generated during and/or analysed during the current study are available from the corresponding author on reasonable request

\section{References}

1. Alongi DM (2020) Global Significance of Mangrove Blue Carbon in Climate Change Mitigation. Sci 2(57), 115. 
2. Alongi DM (2002) Present state and future of the world's mangrove forests. Environ Conserv 29(3):331-349.

3. Andradi-Brown DA, Howe C, Mace, GM, Knight, AT (2013). Do mangrove forest restoration or rehabilitation activities return biodiversity to pre-impact levels? Environmental Evidence 2(1), 20. doi:10.1186/2047-2382-220

4. Basu, SK, Cetzal-Ix, W (2018) Traditional honey collectors in the Sunderbans region and their impact on the local mangrove ecosystem and biodiversity: a case study with particular reference to human-animal conflict Biodiversity 1-7. doi:10.1080/14888386.2018.1508365

5. BTNKJ 2020. Statistics in Karimunjawa National Park figures. Karimunjawa National Park Hall, Ministry of Environment and Forestry.

6. Cameron C, Lindsay BH, Daniel AF, Ben B (2019) High greenhouse gas emissions mitigation benefits from mangrove rehabilitation in Sulawesi, Indonesia. Ecosystem Services 40, 1-9.

7. Carugati L, Gatto B, Rastelli E, Lo Martire M, Coral C, Greco S, Danovaro R (2018) Impact of mangrove forests degradation on biodiversity and ecosystem functioning. Scientific Reports, 8(1). doi:10.1038/s41598-01831683-0

8. Datta D, Guha RN, Chattopadhyay (2010) Application of criteria and indicators in community based sustainable mangrove management in the Sunderbans, India. Ocean \& Coastal Management 53, 468-477.

9. Datta D, Chattopadhyay RN, Guha P (2012) Community based mangrove management: A review on status and sustainability. Journal of Environmental Management 107, 84-95.

10. Hadiyanto, Halim MAR, Muhammad F, Soeprobowati TR, Sularto. Potential for Environmental Services Based on the Estimation of Reserved Carbon in the Mangunharjo Mangrove Ecosystem. Polish Journal of Environmental Studies 30(4):3545-3552. 2021

11. Halim MAR, Rahmila YI, Muhammad F, Safitri Y (2018) The Effect on Mangrove Density with Sediment Rate in Coastal Pasar Banggi of Rembang Regency. E3S Web of Conferences. 73:04020.

12. Ha TTT, Han VD, Simon RB (2012) Mangrove conservation or shrimp farmer's livelihood? The devolution of forest management and benefit sharing in the Mekong Delta, Vietnam. Ocean \& Coastal Management 69, 185-193.

13. Ha TTP, Han VD, Leontine V (2014) Impacts of changes in mangrove forest management practices onforest accessibility and livelihood: A case study in mangrove-shrimp farming system in Ca Mau Province, Mekong Delta, Vietnam. Land Use Policy 36, 89-101.

14. Huxham M, Lucy E, James K, Fridah M, Hassan A, Tabitha M, Fiona N, Robert AB (2015) Applying Climate Compatible Development and economic valuation to coastal management: A case study of Kenya's mangrove forests. Journal of Environmental Management 157, 168-181.

15. Komiyama A, Ong JE, Poungparn S (2008) Allometry, biomass and productivity of mangrove forests: a review. Aquat Bot. 89:128-137.

16. Komiyama A, Poungparn S, Kato S. 2005. Common allometric equations for estimating the tree weight of mangroves. J Trop Ecol. 21:471-477.

17. Li J, Liao Q, Li M, Zhang J, Tam NF, Xu R (2010) Community Structure and Biodiversity of Soil Ciliates at Dongzhaigang Mangrove Forest in Hainan Island, China. Applied and Environmental Soil Science 1-8. doi:10.1155/2010/103819 
18. Malik A, Fensholt R, Mertz O (2015) Mangrove exploitation effects on biodiversity and ecosystem services. Biodiversity and Conservation, 24(14), 3543-3557. doi:10.1007/s10531-015-1015-4

19. Mangora MM (2011) Poverty and institutional management stand-off: a restoration and conservation dilemma for mangrove forests of Tanzania. Wetlands Ecol Manage 19, 533-543.

20. Moriizumi Y, Naohiro M, Hiroki H (2010) Simplified life cycle sustainability assessment of mangrove management: a case of plantation on wastelands in Thailand. Journal of Cleaner Production 18, 1629-1638.

21. Morton B (2016) Hong Kong's mangrove biodiversity and its conservation within the context of a southern Chinese megalopolis. A review and a proposal for Lai Chi Wo to be designated as a World Heritage Site. Regional Studies in Marine Science, 8, 382-399. doi:10.1016/j.rsma.2016.05.001

22. Oliver TSN, Kerrylee R, Chris JC, Colin DW (2012) Measuring, mapping and modelling: an integrated approach to the management of mangrove and saltmarsh in the Minnamurra River estuary, southeast Australia. Wetlands Ecol Manage 20, 353-371.

23. Ortega-Pacheco D, Mendoza-Jimenez MJ, Herrera P (2018) Mangrove Conservation Policies in the Gulf of Guayaquil. Handbook of Climate Change and Biodiversity, 25-43. doi:10.1007/978-3-319-98681-4_2

24. Owuor MA, Mulwa R, Otieno P, Icely J, Newton A (2019) Valuing mangrove biodiversity and ecosystem services: A deliberative choice experiment in Mida Creek, Kenya. Ecosystem Services, 40, 101040. doi:10.1016/j.ecoser.2019.101040

25. Pollisco F, Simorangkir D (2013) The economics of ecosystems and biodiversity, REDD+ and climate change in mangrove ecosystems of Southeast Asia. International Journal of Rural Law and Policy, (1):1-6. doi:10.5130/ijrlp.i1.2013.3350

26. Rahmila YI, Halim MAR (2018) Mangrove forest development determined for ecotourism in Mangunharjo Village Semarang. E3S Web of Conferences. 73:04010.

27. Roy AKD, Khorshed A, Jeff G (2012) A review of the role of property rights and forest policies in the management of the Sundarbans Mangrove Forest in Bangladesh. Forest Policy and Economics 15, 46-53.

28. Roy AKD, Khorshed A, Jeff G (2013) Community perceptions of state forest ownership and management: A case study of the Sundarbans Mangrove Forest in Bangladesh. Journal of Environmental Management 117, 141-149.

29. Santos LCM, Humberto RM, Yara SN, Marília CL, Marisa DB, Nico K, Farid DG (2014) Anthropogenic activities on mangrove areas (São Francisco River Estuary, Brazil Northeast): A GIS-based analysis of CBERS and SPOT images to aid in local management. Ocean \& Coastal Management 89, 39-50.

30. Sarathchandra C, Kambach S, Ariyarathna S, Xu J, Harrison R, Wickramasinghe S (2018) Significance of Mangrove Biodiversity Conservation in Fishery Production and Living Conditions of Coastal Communities in Sri Lanka. Diversity, 10(2), 20. doi:10.3390/d10020020

31. Sarker SK, Reeve R, Paul NK, Matthiopoulos J (2019) Modelling spatial biodiversity in the world's largest mangrove ecosystem-The Bangladesh Sundarbans: A baseline for conservation. Diversity and Distributions. doi:10.1111/ddi.12887

32. Sidik F, Bambang S, Haruni K, Muhammad ZM (2018) Mangrove conservation for climate change mitigation in Indonesia. WIREs Clim Change 1-9 9:e529.

33. Syahid LN, Sakti AD, Virtriana R, Wikantika K, Windupranata W, Tsuyuki S, Caraka RE, Pribadi R (2021) Determining Optimal Location for Mangrove Planting Using Remote Sensing and Climate Model Projection in 
Southeast Asia. RemoteSensing.;12(22):3734.doi:10.3390/rs12223734. 2020

34. Taillardat P. Daniel AF, Massimo L (2018) Mangrove blue carbon strategies for climate change mitigation are most effective at the national scale. Biology Letters 14, 1-6.

35. Thatoi H, Behera BC, Mishra RR, Dutta SK (2012) Biodiversity and biotechnological potential of microorganisms from mangrove ecosystems: a review. Annals of Microbiology, 63(1), 1-19. doi:10.1007/s13213-012-0442-7

36. Wan Talaat, WIA, Tahir NM, Husain ML (2012) The Existing Legislative, Administrative and Policy Framework for the Mangrove Biodiversity Management \& Conservation in Malaysia. Journal of Politics and Law 5(1). doi:10.5539/jpl.v5n1p180

37. Wickramasinghea S, Maurizio B, Sarath WK, Roland C, Alfredo JA, Oleg VS (2009) Multi-functional pollution mitigation in a rehabilitated mangrove conservation area. Ecological Engineering 35, 898-907.

38. Zhila H, Mahmood H, Rozainah MZ (2013) Biodiversity and biomass of a natural and degraded mangrove forest of Peninsular Malaysia. Environmental Earth Sciences, 71(11), 4629-4635. doi:10.1007/s12665-0132853-6

\section{Figures}




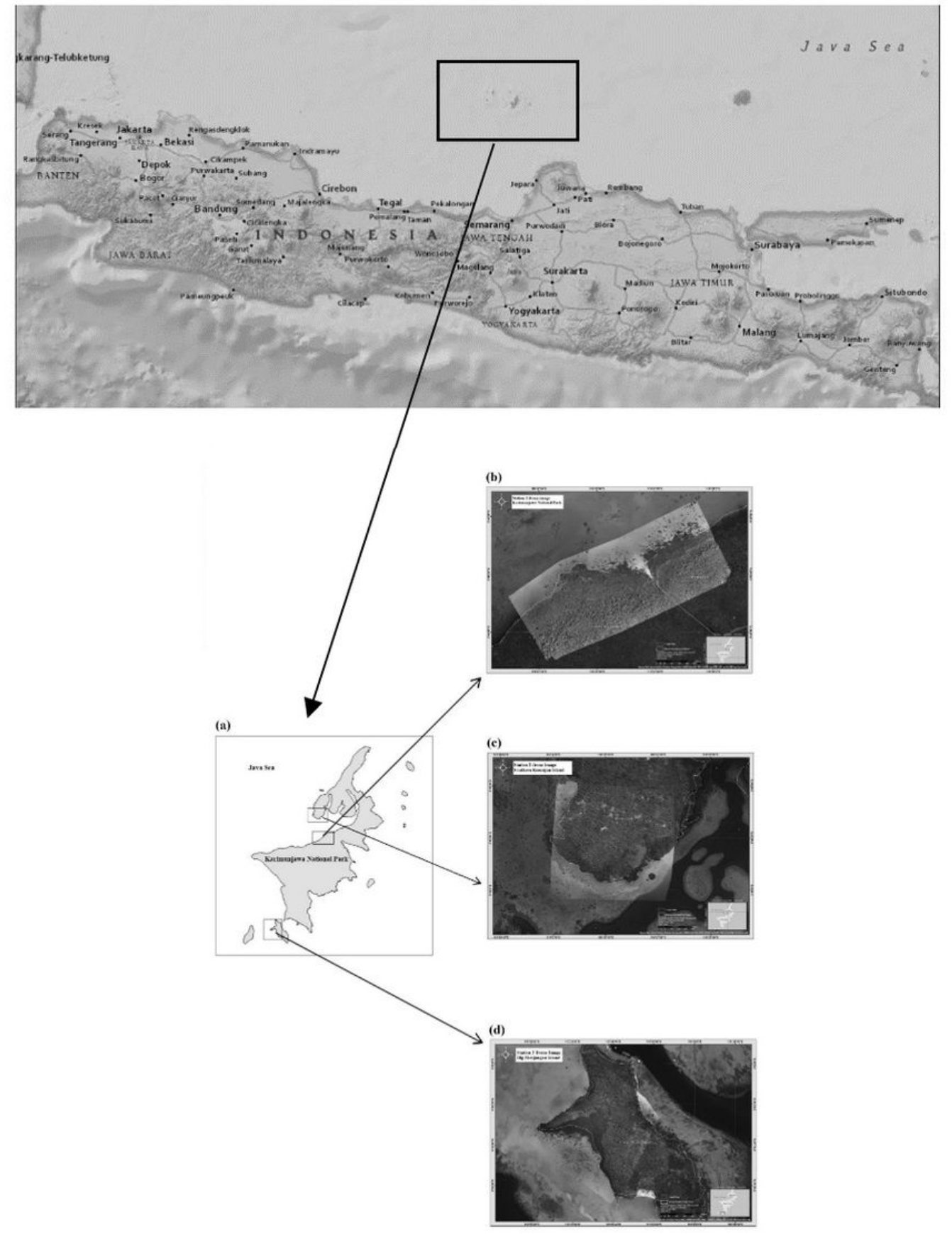

\section{Figure 1}

Map of (a) Karimunjawa National Park Area, Jepara Regency, Central Java (b) Karimunjawa Island (c) Kemujan Island (d) Menjangan Islan 
Station 1

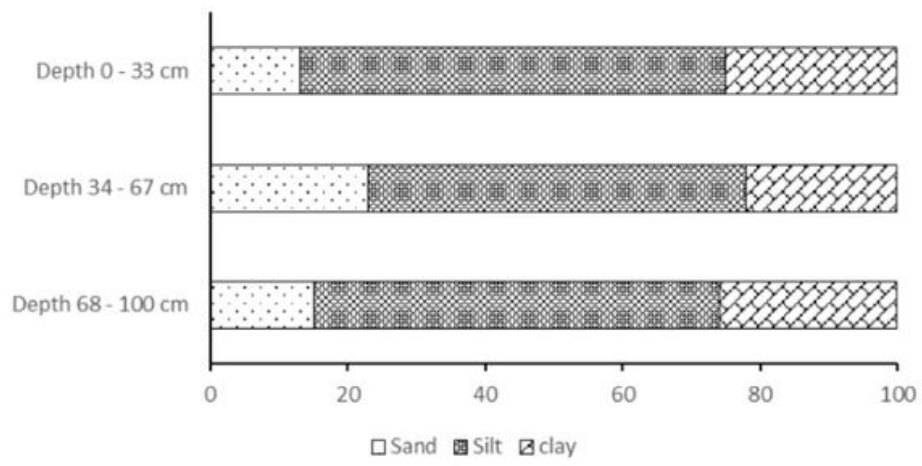

Station 2

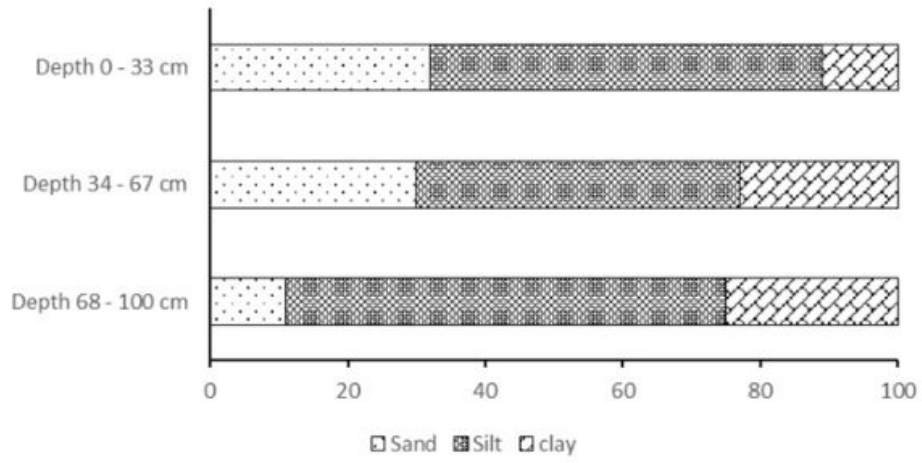

Station 3

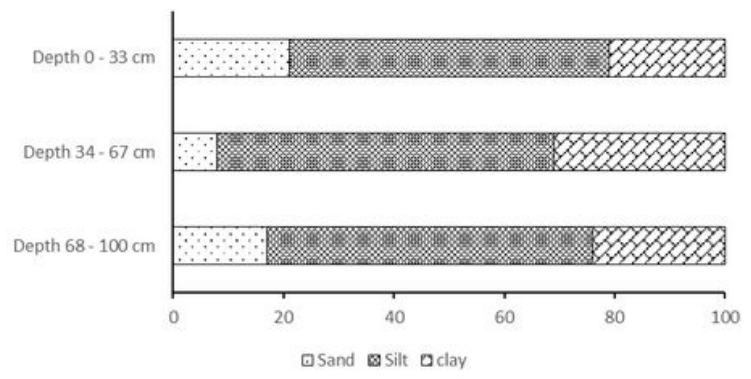

Figure 2

Type and amount of sediment percentage based on depth

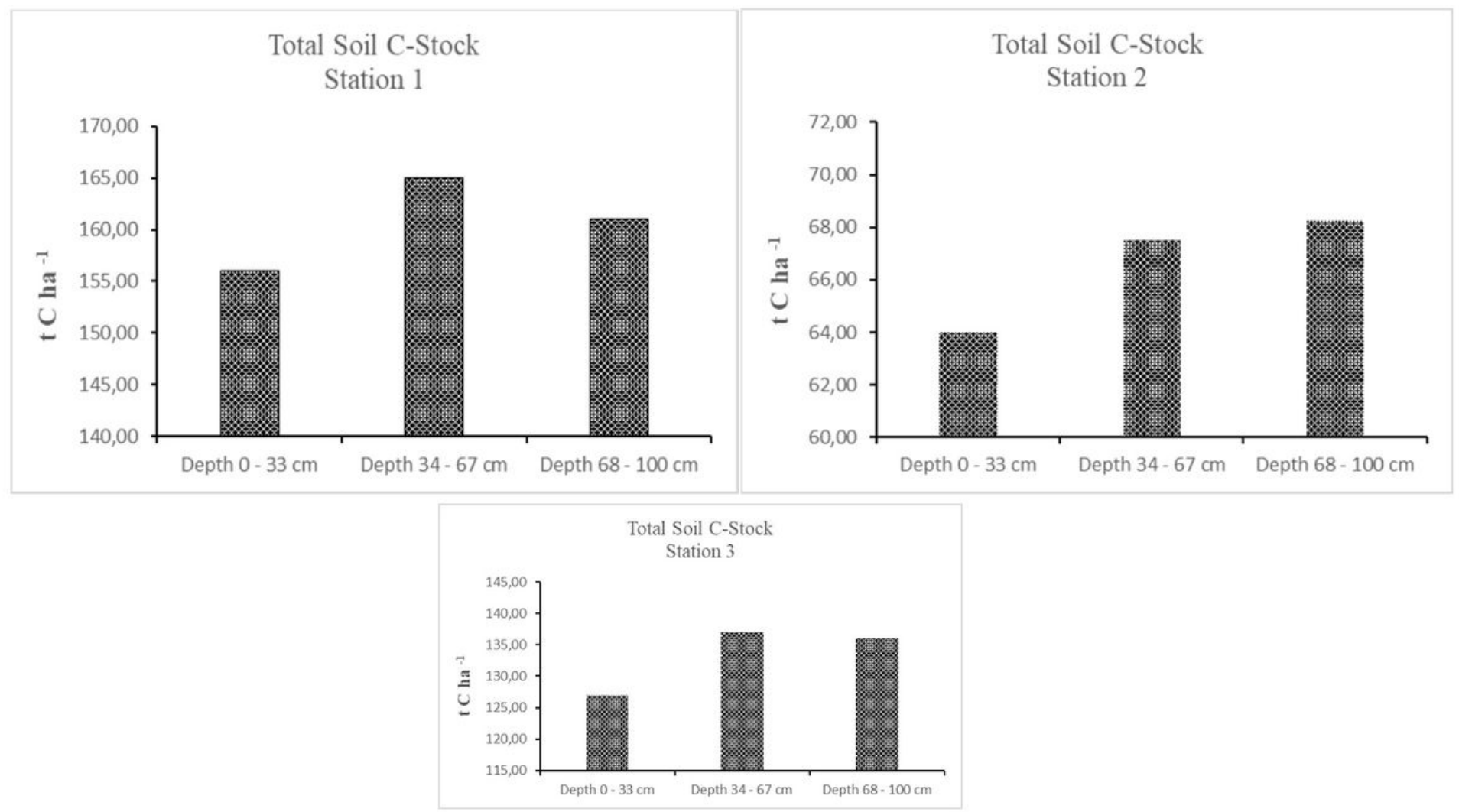




\section{Figure 3}

Comparison of total soil C-stock values based on depth at all stations 